\title{
Wells syndrome
}

INSERM

\section{Source}

INSERM. (1999). Orphanet: an online rare disease and orphan drug data base. Wells syndrome. ORPHA:901

Wells syndrome is characterised by the presence of recurrent cellulitis-like eruptions with eosinophilia. 